University of Nebraska - Lincoln

DigitalCommons@University of Nebraska - Lincoln

$4-15-2004$

\title{
Influenza Vaccination Coverage among Adults with Asthma: Findings from the 2000 Behavioral Risk Factor Surveillance System
}

\author{
Earl S. Ford \\ Seymour G. Williams \\ David M. Mannino \\ Stephen C. Redd
}

Follow this and additional works at: https://digitalcommons.unl.edu/publichealthresources

Part of the Public Health Commons

Ford, Earl S.; Williams, Seymour G.; Mannino, David M.; and Redd, Stephen C., "Influenza Vaccination Coverage among Adults with Asthma: Findings from the 2000 Behavioral Risk Factor Surveillance System" (2004). Public Health Resources. 20.

https://digitalcommons.unl.edu/publichealthresources/20

This Article is brought to you for free and open access by the Public Health Resources at DigitalCommons@University of Nebraska - Lincoln. It has been accepted for inclusion in Public Health Resources by an authorized administrator of DigitalCommons@University of Nebraska - Lincoln. 


\section{BRIEF OBSERVATIONS}

Influenza Vaccination Coverage among Adults with Asthma: Findings from the 2000 Behavioral Risk Factor Surveillance System

Earl S. Ford, MD, MPH, Seymour G. Williams, MD, David M. Mannino, MD, Stephen C. Redd, MD

$\mathrm{T}$ The prevalence of asthma has increased substantially in the United States since 1980 (1). The primary clinical and public health strategy to reduce the burden of asthma is to prevent exacerbation of the disease, of which upper and lower respiratory tract infections are a major cause (2-5). One such infection-influenza-and its complications are potentially preventable with annual vaccination, which is a safe and effective method $(6,7)$, including among persons with asthma (8). Because persons with asthma are at increased risk of complications from influenza, they are advised to receive annual influenza vaccinations (9), unless there are contraindications.

Little is known about how adults with asthma or health care providers comply with the annual influenza vaccination recommendations issued by the Advisory Committee on Immunization Practices (9). Among children with asthma, however, vaccination levels are low $(10-15)$. We therefore sought to assess the influenza vaccination coverage among adults with asthma, as well as to identify predictors of receiving such a vaccination.

\section{METHODS}

Data are from the 2000 Behavioral Risk Factor Surveillance System, an annual standardized state-based telephone survey of risk factors for chronic disease (16). Health agencies in the 50 states, the District of Columbia, and three U.S. territories (Guam, Puerto Rico, and the Virgin Islands) selected for interview an independent probability sample of noninstitutionalized adult residents aged $\geq 18$ years who were living households that had telephones. All states used an identical core questionnaire administered over the telephone by trained interviewers. The survey was reviewed and approved by the human subjects office at the Centers for Disease Control and Prevention.
Respondents were asked, "Did a doctor ever tell you that you had asthma?" Those who responded "yes" were then asked, "Do you still have asthma?" Respondents who answered affirmatively to both questions were classified as having "current" asthma. In 17 states, participants were also asked, "During the past 12 months, have you had a flu shot?"

We examined the percentages of participants with asthma who reported having an influenza vaccination, by age, sex, race or ethnicity, and education. Direct age adjustment was performed using the age distribution of the U.S. population in 2000. We used logistic regression analysis to examine the independent associations of age, sex, race or ethnicity, education, health status, health insurance status, time since the last checkup, and state of origin with vaccination status. Health status was determined from the question "Would you say that in general your health is excellent, very good, good, fair, or poor?" Insurance status was determined from four questions. Time since the last checkup was determined from the question "About how long has it been since you last visited a doctor for a routine checkup?" Answers included the following: within the past year (1 to 12 months ago), within the past 2 years ( 1 to 2 years ago), within the past 5 years ( 2 to 5 years ago), 5 or more years ago, and never.

\section{Statistical Analysis}

Analyses were conducted with SUDAAN (Research Triangle Institute, Research Triangle Park, North Carolina) to produce valid estimates of the variance (17).

\section{RESULTS}

From 17 states, we included in our analysis 3939 participants with current asthma who were aged $\geq 18$ years and had complete data. The mean age was 45 years (range, 18 to 96 years); $40 \%$ were men; $83 \%$ were white; and the mean length of education was 14 years.

Overall, $41 \%$ of participants with asthma reported having received an influenza vaccination during the preceding year. Influenza vaccination levels were $27 \%$ among participants aged 18 to 49 years, $56 \%$ among those aged 50 to 64 years, and $75 \%$ among those aged $\geq 65$ years.

In univariate analyses, age, sex, race or ethnicity, health status, medical insurance, and time since the last physician visit were associated with vaccination status $(P=$ 0.05 for sex; $<0.001$ for all other variables); education was not $(P=0.30)$. In a multivariate analysis, all of these univariate associations, except for sex, continued to be significant (Table 1). In addition, after adjusting for age (and other variables), higher levels of education were associated with being vaccinated (Table 1). 
Table 1. Characteristics Associated with Influenza Vaccination among Persons with Asthma

\begin{tabular}{|c|c|c|c|}
\hline Variable & $\begin{array}{l}\text { Number of } \\
\text { Participants }\end{array}$ & $\begin{array}{c}\text { Number } \\
\text { Vaccinated }(\%)^{*}\end{array}$ & $\begin{array}{c}\text { Adjusted Odds Ratio }{ }^{\dagger} \\
\text { (95\% Confidence Interval) }\end{array}$ \\
\hline \multicolumn{4}{|l|}{ Age (years) } \\
\hline $18-49$ & 2306 & $670(27)$ & 1.0 \\
\hline $50-64$ & 900 & $512(56)$ & $2.8(2.1-3.7)$ \\
\hline$\geq 65$ & 733 & $544(75)$ & $5.0(3.0-8.4)$ \\
\hline \multicolumn{4}{|l|}{ Sex } \\
\hline Male & 1134 & $472(37)$ & 1.0 \\
\hline Female & 2805 & $1254(43)$ & $1.2(0.9-1.6)$ \\
\hline \multicolumn{4}{|l|}{ Race or ethnicity } \\
\hline White & 3255 & $1490(44)$ & 1.0 \\
\hline African American & 363 & $122(28)$ & $0.5(0.3-0.7)$ \\
\hline Mexican American & 169 & $55(27)$ & $0.6(0.4-1.0)$ \\
\hline Other & 152 & $59(46)$ & $1.0(0.6-1.9)$ \\
\hline \multicolumn{4}{|l|}{ Education } \\
\hline$<$ High school & 569 & $286(44)$ & 1.0 \\
\hline $\begin{array}{l}\text { High school/general } \\
\text { equivalency diploma }\end{array}$ & 1212 & $487(38)$ & $1.1(0.8-1.7)$ \\
\hline Some college & 1188 & $521(40)$ & $1.6(1.1-2.4)$ \\
\hline Postgraduate & 970 & $432(45)$ & $2.2(1.4-3.5)$ \\
\hline \multicolumn{4}{|l|}{ Health status } \\
\hline Excellent & 469 & $167(37)$ & 1.0 \\
\hline Very good & 1081 & $411(32)$ & $0.9(0.6-1.4)$ \\
\hline Good & 1253 & $535(41)$ & $1.2(0.8-1.8)$ \\
\hline Fair & 696 & $350(44)$ & $1.3(0.8-2.1)$ \\
\hline Poor & 440 & $263(66)$ & $2.4(1.3-4.3)$ \\
\hline \multicolumn{4}{|l|}{ Insurance } \\
\hline Private & 2320 & $911(36)$ & 1.00 \\
\hline Medicare & 1008 & $673(66)$ & $1.4(0.8-2.2)$ \\
\hline Medicaid & 234 & $82(40)$ & $1.1(0.6-1.8)$ \\
\hline None & 377 & $60(18)$ & $0.5(0.3-0.8)$ \\
\hline \multicolumn{4}{|c|}{ Time since last checkup (years) } \\
\hline$<1$ & 3107 & $1498(46)$ & 1.0 \\
\hline $1-2$ & 387 & $119(33)$ & $0.8(0.5-1.3)$ \\
\hline $2-5$ & 196 & $56(27)$ & $0.6(0.4-1.2)$ \\
\hline$>5$ & 230 & $49(24)$ & $0.5(0.3-0.9)$ \\
\hline Never & 19 & $4(16)$ & $0.2(0.0-1.0)$ \\
\hline
\end{tabular}

* Percentages were calculated using sampling weights. Standard errors range from $2 \%$ to $10 \%$.

${ }^{\dagger}$ Adjusted for all variables shown in Table.

Influenza vaccination levels varied almost twofold among the states that had included the influenza vaccination question in their surveys (Table 2): South Dakota $(61 \%)$ had the highest coverage and New Jersey (32\%) had the lowest. After adjusting for the variables in Table 1 , these differences among states remained $(P=0.001)$.

\section{DISCUSSION}

We found that influenza vaccination levels were generally low among adults with asthma. Only $41 \%$ of adults with asthma reported being vaccinated during the previous year: $27 \%$ of participants aged 18 to 49 years, $56 \%$ of those aged 50 to 64 years, and $75 \%$ of those aged $\geq 65$ years. Furthermore, there was substantial interstate vari- ation in the percentage of participants who were vaccinated. During 1999 to 2001, vaccination levels in the general population ranged from $64 \%$ to $68 \%$ among people aged $\geq 65$ years and from $32 \%$ to $38 \%$ among those aged 50 to 64 years $(9)$.

Influenza and asthma are important sources of morbidity and mortality in the United States. Each year, about 114,000 excess hospitalizations and 36,000 deaths are attributed to influenza (9). In 1999, about 10.5 million people reported having one or more asthma attacks during the past 12 months (1). Influenza may be responsible for as many as $19 \%$ of asthma attacks or exacerbations in children and adults $(2,18,19)$. Because inactivated influenza vaccine may prevent about $70 \%$ to $90 \%$ of influenza illnesses among people aged $<65$ years during 
Table 2. Influenza Vaccination Coverage among Persons with Asthma, by State

\begin{tabular}{lccc}
\hline \multicolumn{1}{c}{ State } & $\begin{array}{c}\text { Number of } \\
\text { Participants }\end{array}$ & $\begin{array}{c}\text { Number } \\
\text { Vaccinated }(\%)^{*}\end{array}$ & $\begin{array}{c}\text { Adjusted Odds Ratio } \\
(95 \% \text { Confidence Interval) }\end{array}$ \\
\hline South Dakota & 274 & $168(61)$ & $2.9(1.8-4.7)$ \\
Nebraska & 195 & $101(51)$ & $1.9(1.2-3.1)$ \\
North Dakota & 135 & $61(49)$ & $2.0(1.1-3.6)$ \\
Arizona & 198 & $86(48)$ & $1.6(0.8-3.0)$ \\
Minnesota & 206 & $98(46)$ & $1.6(1.0-2.6)$ \\
South Carolina & 231 & $110(46)$ & $1.9(1.2-3.2)$ \\
Tennessee & 233 & $102(46)$ & $1.3(0.8-2.2)$ \\
North Carolina & 217 & $102(45)$ & $1.5(0.9-2.4)$ \\
Vermont & 256 & $115(44)$ & $1.6(1.0-2.5)$ \\
Iowa & 227 & $107(42)$ & $1.8(1.1-3.1)$ \\
Virginia & $56(42)$ & $1.7(1.1-2.8)$ \\
California & 129 & $124(41)$ & $1.3(0.8-2.1)$ \\
Ohio & 299 & $90(38)$ & $1.1(0.7-1.7)$ \\
Kansas & 263 & $128(37)$ & $1.2(0.7-2.1)$ \\
Montana & 329 & $109(37)$ & $1.1(0.7-1.9)$ \\
Georgia & 245 & $94(33)$ & $1.0($ Reference) \\
New Jersey & 258 & $75(32)$ & \\
\hline
\end{tabular}

* Percentages were calculated using sampling weights. Standard errors range from $2 \%$ to $10 \%$.

${ }^{\dagger}$ Adjusted for age, sex, race or ethnicity, education, health status, insurance, and time since last checkup.

the years when the vaccine and circulating influenza strain match (9), vaccination could substantially reduce influenza-associated morbidity among persons with asthma.

Estimating the excess morbidity, mortality, and health care use among persons with asthma who do not receive an influenza vaccination is difficult because the benefits to patients with asthma have not been well established and the cost-effectiveness of routinely vaccinating people with asthma is not well defined (20). A recent study showed that the vaccine effectiveness in reducing hospitalizations for pneumonia and influenza or all-cause mortality ranged from $27 \%$ to $48 \%$ among persons aged $\geq 65$ years with lung conditions that included asthma (21).

Our analysis of data from the Behavioral Risk Factor Surveillance System shows that $73 \%$ of participants with asthma reported seeing a provider during the past 12 months. For those who do see a health care provider on a regular basis, opportunities exist for physicians and their staff to discuss the need for vaccination or to administer the vaccine. Furthermore, there is a range of patient-, provider-, and system-specific strategies for improving vaccination coverage, including sending computerized reminder letters, implementing patient reminder/recall systems, and using audit and feedback (22-24). The Centers for Disease Control and Prevention has summarized strategies for improving vaccination coverage among adults (25). In addition, physicians may need to address other concerns about influenza vaccination that are more specific to persons with asthma, such as effects of the vaccine while taking inhaled corticosteroids or increased risk of allergic reactions to vaccine components.

Some of the predictors of vaccination status that we found, such as age, health status, and medical insurance, have been described by others $(26,27)$. Thus, to reach groups with low coverage of influenza vaccination, interventions should be aimed at young adults, African Americans, Mexican Americans, and those without insurance. The variation in vaccination levels among states suggests that states with higher levels may employ strategies that other states could use to improve their vaccination levels.

Several limitations should be considered when interpreting our results. All data were self-reported and subject to misclassification; however, the validity of self-reported asthma (28-30) and influenza vaccination status (31-35) has been demonstrated. Because our results are based on the 17 states that administered the question about influenza vaccination, these results are not nationally representative. Additionally, the survey did not include institutionalized adults and households without telephones.

In general, influenza vaccination levels have increased among adults aged $\geq 65$ years in the United States, although the trend among people with asthma is unknown (9). Should the general favorable trend continue, progress will be made in achieving the objectives of the Healthy People 2010, which call for $90 \%$ of noninstitutionalized adults aged $\geq 65$ years and $60 \%$ of noninstitutionalized high-risk adults (including persons with asthma) aged 18 to 64 years to undergo annual influenza vaccinations (36). 


\section{REFERENCES}

1. Centers for Disease Control and Prevention. Surveillance for asthma-United States, 1980-1999. MMWR Morb Mortal Wkly Rep. 2002;51(SS-1):1-13.

2. Teichtahl H, Buckmaster N, Pertnikovs E. The incidence of respiratory tract infection in adults requiring hospitalization for asthma. Chest. 1997;112:591-596.

3. Neuzil KM, Wright PF, Mitchel EF Jr, Griffin MR. The burden of influenza illness in children with asthma and other chronic medical conditions. J Pediatr. 2000;137:856-864.

4. Tuffaha A, Gern JE, Lemanske RF Jr. The role of respiratory viruses in acute and chronic asthma. Clin Chest Med. 2000;21:289-300.

5. Nathan RA, Geddes D, Woodhead M. Management of influenza in patients with asthma or chronic obstructive pulmonary disease. Ann Allergy Asthma Immunol. 2001;87:447-454 , 487.

6. Gross PA, Hermogenes AW, Sacks HS, et al. The efficacy of influenza vaccine in elderly persons. A meta-analysis and review of the literature. Ann Intern Med. 1995;123:518-527.

7. Beyer WE, de Bruijn IA, Palache AM, et al. Protection against influenza after annually repeated vaccination: a meta-analysis of serologic and field studies. Arch Intern Med. 1999;159:182-188.

8. American Lung Association Asthma Clinical Research Centers. The safety of inactivated influenza vaccine in adults and children with asthma. N Engl J Med. 2001;345:1529-1536.

9. Centers for Disease Control and Prevention. Prevention and control of influenza. Recommendations of the Advisory Committee on Immunization Practices (ACIP). MMWR Morb Mortal Wkly Rep. 2003;52(RR08):1-36.

10. Carter WB, Beach LR, Inui TS, et al. Developing and testing a decision model for predicting influenza vaccination compliance. Health Serv Res. 1986;20(6 pt 2):897-932.

11. Hall CB. Influenza: a shot or not? Pediatrics. 1987;79:564-566.

12. Szilagyi PG, Rodewald LE, Savageau J, et al. Improving influenza vaccination rates in children with asthma: a test of a computerized reminder system and an analysis of factors predicting vaccination compliance. Pediatrics. 1992;90:871-875.

13. Chung EK, Casey R, Pinto-Martin JA, et al. Routine and influenza vaccination rates in children with asthma. Ann Allergy Asthma Immunol. 1998;80:318-322.

14. Kramarz P, DeStefano F, Gargiullo PM, et al. Influenza vaccination in children with asthma in health maintenance organizations. Vaccine Safety Datalink Team. Vaccine. 2000;18:2288-2294.

15. Kramarz P, DeStefano F, Gargiullo PM, et al. Does influenza vaccination prevent asthma exacerbations in children? J Pediatr. 2001; 138:306-310.

16. Nelson DE, Holtzman D, Bolen J, Stanwyck CA, et al. Reliability and validity of measures from the Behavioral Risk Factor Surveillance System (BRFSS). Soz Praventivmed. 2001;46(suppl 1):S3-S42.

17. Shah BV, Barnwell BG, Bieler GS. SUDAAN User's Manual, Version 7.5. Research Triangle Park, North Carolina: Research Triangle Institute; 1997.

18. Johnston SL, Pattemore PK, Sanderson G, et al. Community study of role of viral infections in exacerbations of asthma in 9-11 year old children. BMJ. 1995;310:1225-1229.

19. Atmar RL, Guy E, Guntupalli KK, et al. Respiratory tract viral infections in inner-city asthmatic adults. Arch Intern Med. 1998;158: 2453-2459.

20. Cates CJ, Jefferson TO, Bara AI, et al. Vaccines for preventing influenza in people with asthma (Cochrane Review). Cochrane Database Syst Rev 2000;(4):CD000364.

21. Hak E, Nordin J, Wei F, et al. Influence of high-risk medical conditions on the effectiveness of influenza vaccination among elderly members of 3 large managed-care organizations. Clin Infect Dis. 2002;35:370-377.

22. Bedford D, Howell F, Corcoran R. The provision of influenza vaccine to patients over 65 years by general practitioners. Ir Med J. 1997;90:231-232.

23. Clayton Bordley W, Chelminski A, Margolis PA, et al. The effect of audit and feedback on immunization delivery: a systematic review. Am J Prev Med. 2000;18:343-350.

24. Task Force on Community Preventive Services. Recommendations regarding interventions to improve vaccination coverage in children, adolescents, and adults. Task Force on Community Preventive Services. Am J Prev Med. 2000;18(1 suppl):92-96.

25. Centers for Disease Control and Prevention. Strategies for increasing adult vaccination rates. Available at: http://www.cdc.gov/nip/ publications/flustrat.htm. Accessed on September 5, 2003.

26. van Essen GA, Kuyvenhoven MM, de Melker RA. Compliance with influenza vaccination. Its relation with epidemiologic and sociopsychological factors. Arch Fam Med. 1997;6:157-162.

27. Opstelten W, Hak E, Verheij TJ, van Essen GA. Introducing a pneumococcal vaccine to an existing influenza immunization program: vaccination rates and predictors of noncompliance. Am J Med. 2001;111:474-479.

28. Harlow SD, Linet MS. Agreement between questionnaire data and medical records. The evidence for accuracy of recall. Am J Epidemiol. 1989;129:233-248.

29. Linet MS, Harlow SD, McLaughlin JK, McCaffrey LD. A comparison of interview data and medical records for previous medical conditions and surgery. J Clin Epidemiol. 1989;42:1207-1213.

30. Toren K, Brisman J, Jarvholm B. Asthma and asthma-like symptoms in adults assessed by questionnaires. A literature review. Chest. 1993;104:600-608.

31. Hutchison BG. Measurement of influenza vaccination status of the elderly by mailed questionnaire: response rate, validity and cost. Can J Public Health. 1989;80:271-275.

32. Nichol KL, Korn JE, Baum P. Estimation of outpatient risk characteristics and influenza vaccination status: validation of a self-administered questionnaire. Am J Prev Med. 1991;7:199-203.

33. MacDonald R, Baken L, Nelson A, Nichol KL. Validation of selfreport of influenza and pneumococcal vaccination status in elderly outpatients. Am J Prev Med. 1999;16:173-177.

34. Martin LM, Leff M, Calonge N, Garrett C, Nelson DE. Validation of self-reported chronic conditions and health services in a managed care population. Am J Prev Med. 2000;18:215-218.

35. Bedford D, Howell F. Influenza vaccination uptake in 1999 and older persons recall of vaccination. Ir Med J. 2001;94:264-265.

36. U.S. Department of Health and Human Services (HHS). Healthy People 2010. Washington, D.C.: Health and Human Services; January 2000 .

From the Division of Adult and Community Health (ESF), National Center for Chronic Disease Prevention and Health Promotion, and Division of Environmental Hazards and Health Effects (SGW, DMM, SCR), National Center for Environmental Health, Centers for Disease Control and Prevention, Atlanta, Georgia.

Requests for reprints should be addressed to Earl S. Ford, MD, MPH, Centers for Disease Control and Prevention, 4770 Buford Highway NE, Mailstop K66, Atlanta, Georgia 30341, or eford@cdc.gov.

Manuscript submitted April 18, 2003.Manuscript submitted April 18, 2003, and accepted in revised form November 18, 2003. 